\title{
Information System Design for Monitoring Violations of Traffic Signs
}

\author{
Marson James Budiman \\ Department of Computer Engineering \\ Manado State Polytechnic
}

\author{
Stephy Walukow \\ Department of Computer Engineering \\ Manado State Polytechnic
}

\begin{abstract}
Many people who have not realized traffic, in this case violations of traffic signs are prohibited from parking. It can be found there are still many vehicles parked carelessly, while there are prohibited signs of parking. Vehicles that are arbitrarily parked, greatly affect the movement of vehicles, where vehicles that pass places with high activity, the rate of movement will be hampered by vehicles parked on the roadside, so this can potentially cause congestion. So far, sanctions and actions against traffic violators, especially vehicles parked carelessly, are not carried out because it is difficult to know the violations that occur. The absence of a rapid information system for officers related to parking violations causes congestion in the area and this condition continues and this very annoying for road users. The purpose of this study is to make a free web-based parking detection system with fast information to the Transportation Agency officers. The expected results of this study are information in real time by the Department of Transportation staff if traffic violations occur.
\end{abstract}

\section{Keywords}

Traffic violations, Traffic Signs, Information Systems

\section{INTRODUCTION}

Along with the increasing volume of private vehicles, the need for land facilities as a parking lot is increasing. Parking is a problem that is often found in transportation systems. The parking problems lately greatly affect the movement of vehicles, where vehicles that pass places that have high activity rates will be hampered by parking in the road, so this can potentially cause congestion. Because there are still many people who are not yet aware of traffic rules, even though there are signs that there is no parking. During this time sanctions and actions against traffic violators in particular parked vehicles carelessly, not much was done because it was difficult to know the violations that occurred. Based on these problems the author makes a violation detection system prohibited from parking with a fast complaint information model to Web-based Transportation Service officers. Thus the community will no longer park their vehicles carelessly and the road will avoid traffic jams

\section{METHODOLOGY}

\subsection{Research Design}

At this stage will be carried out to identify the existing problems, in order to be able to anticipate all of the problems associated with entry into the new system. The problems that are identified is a Way to monitor violations of traffic signs.

Designing an application is made to determine the components of the modules forming the application to be designed and the process contained therein using the Unified Modeling Language (UML) which will make the use case diagram, flowchart and of the process of analysis and design of object-oriented. This application runs under the operating system Android. [14]

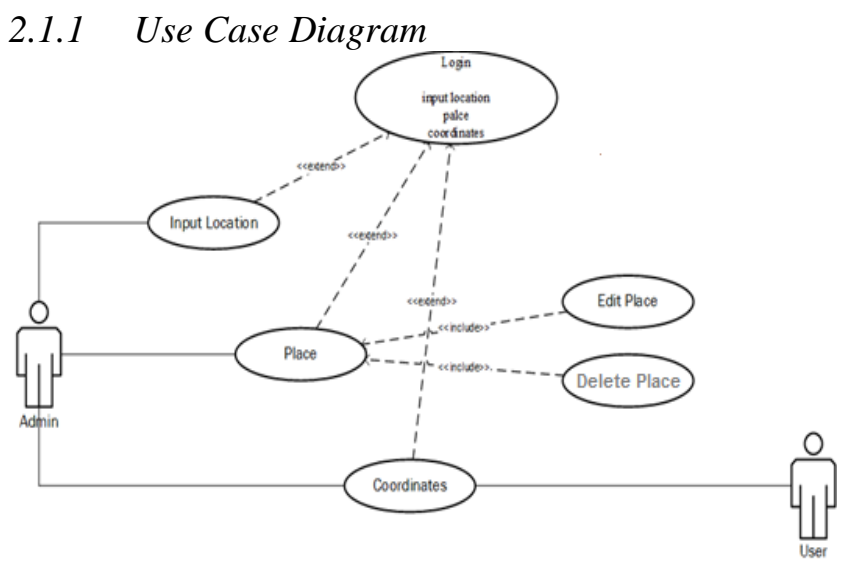

Fig. 1 Use Case Diagram

The use case is used to model all business processes based on the perspective of the system user. Use case diagram consists of diagrams for use cases and actors. Actors represent people who will operate or people who interact with the application system. The use case represents the operations performed by the actor. The case case is described as an ellipse with the name of the operation written in it. Actors who carry out operations are connected in a straight line to the use case.

\subsubsection{Sequence Diagram}

Class diagrams and object diagrams are a picture of a static model. But there are also those that are dynamic, such as Diagram Interaction. Diagram sequences are one of the Interaction diagrams that explain how an operation is performed; what message (message) was sent and when it was implemented. This diagram is organized by time. Objects related to the operation process are sorted from left to right based on the time in which the messages are ordered. 


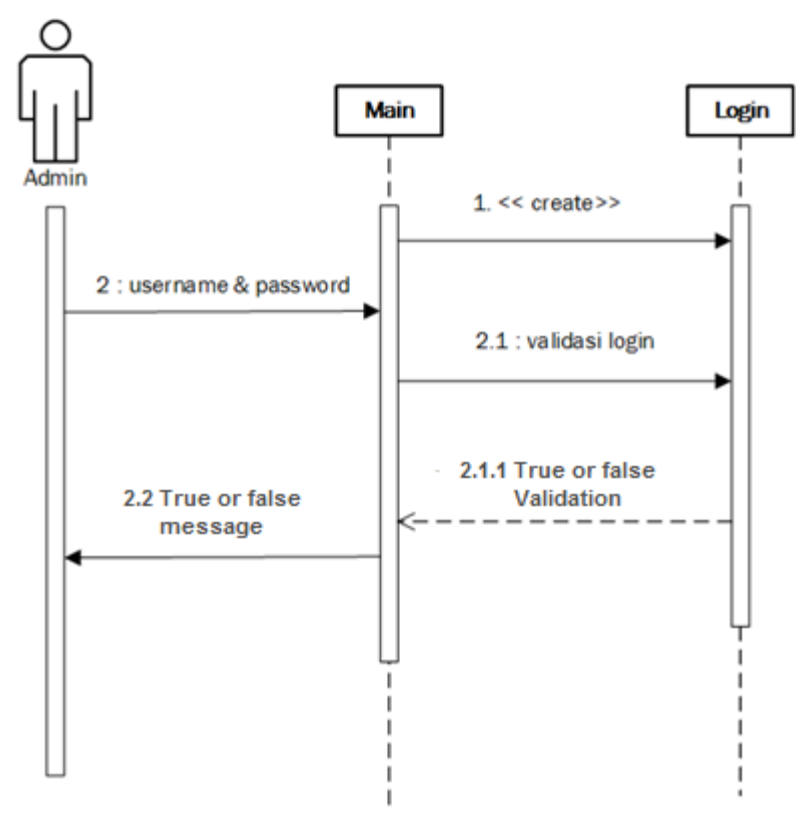

Fig. 2 Sequence Login Admin

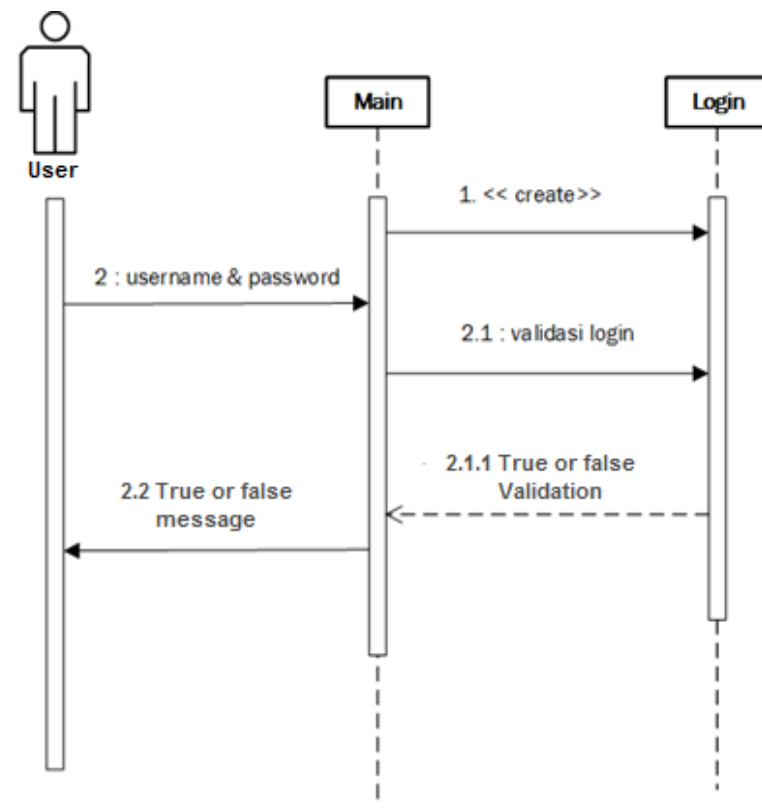

Fig. 3 Sequence Login User

\subsection{Structure of Database Tables}

From the design, the form of the application table structure can be arranged as follows:

1. User table

Serves as a storage of usernames and passwords that have been downloaded by application users

Table 1: Table User

\begin{tabular}{|c|c|c|c|}
\hline Field & Type & Lenght & Keterangan \\
\hline id & int & 8 & Primary Key \\
\hline username & varchar & 64 & \\
\hline password & varchar & 64 & \\
\hline role & int & 1 & \\
\hline
\end{tabular}

2. Table Location
Serves as data storage that has been inputted by the user in the application

Table 2 Table Location

\begin{tabular}{|c|c|c|c|}
\hline Field & Type & Lenght & Information \\
\hline id & int & 8 & \\
\hline Location_desc & text & & \\
\hline lat & varchar & 64 & \\
\hline lng & varchar & 64 & \\
\hline account & int & 8 & Foregin Key \\
\hline
\end{tabular}

\subsection{Flow Chart}

Flowchart or flow chart is a chart (chart) that shows the flow (flow) in the program or system procedures logically. Flowchart is used mainly for communication aids and for documentation. The program flow chart consists of two types, namely the program logic flowchart (program logic flowchart) and detailed computer program flowchart (detailed computer program flowchart). The flowchart of program logic is used to describe each step in the program logically. In making this application it is necessary to create a flowchart to be able to determine the flow of the program so that it will make it easier in making the software to be created.

1. Flowchart Login

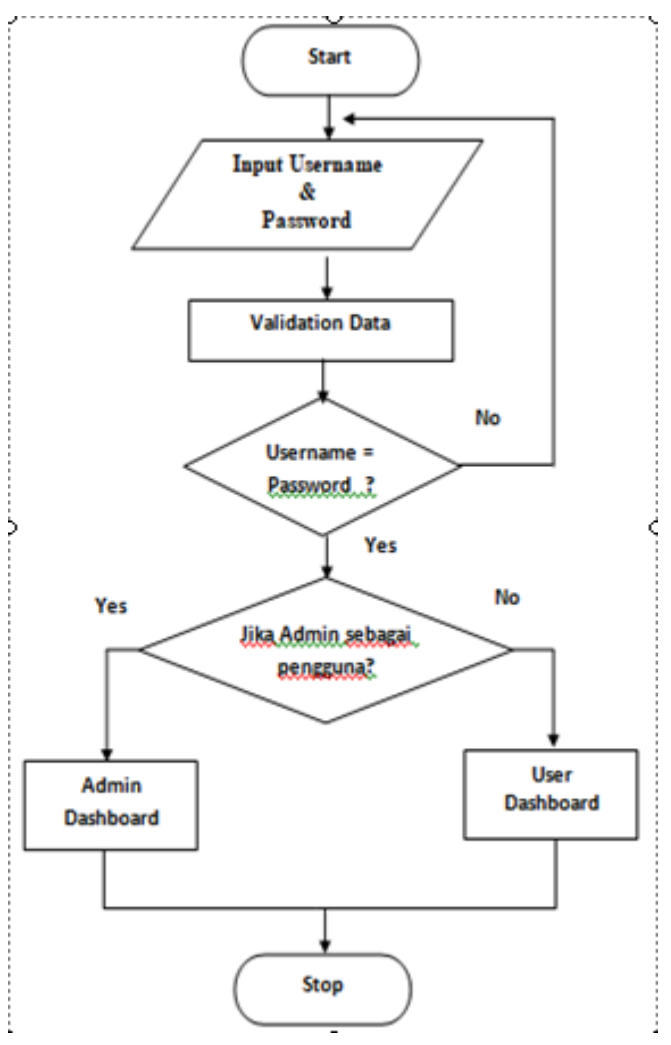

Fig. 4 Flowchart Login 
2. Flowchart Location

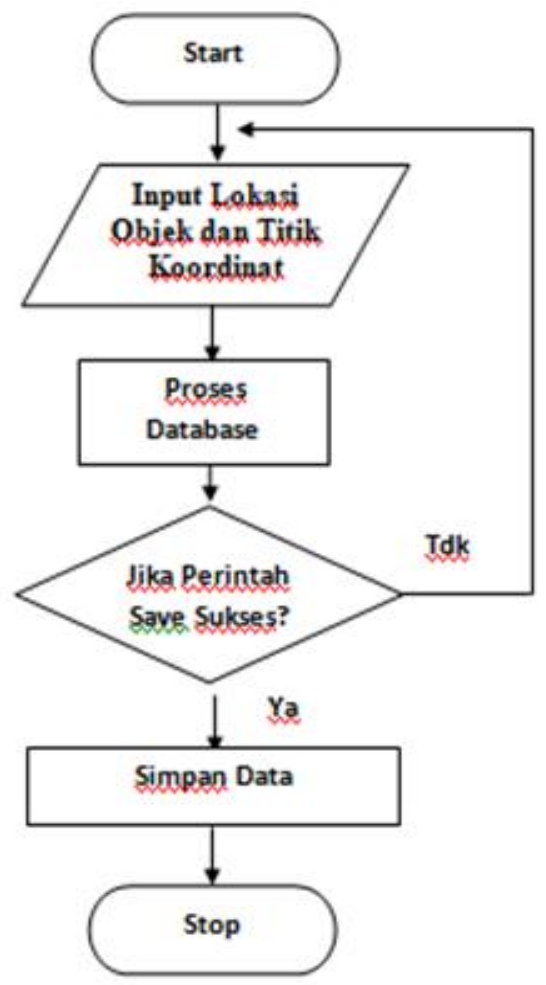

Fig. 5 Flowchart Location

\subsection{Interface Design}

In making software, it is necessary to design an interface so that it makes it easier for users to understand the intent and purpose of the information that will be displayed on the software that will be created.

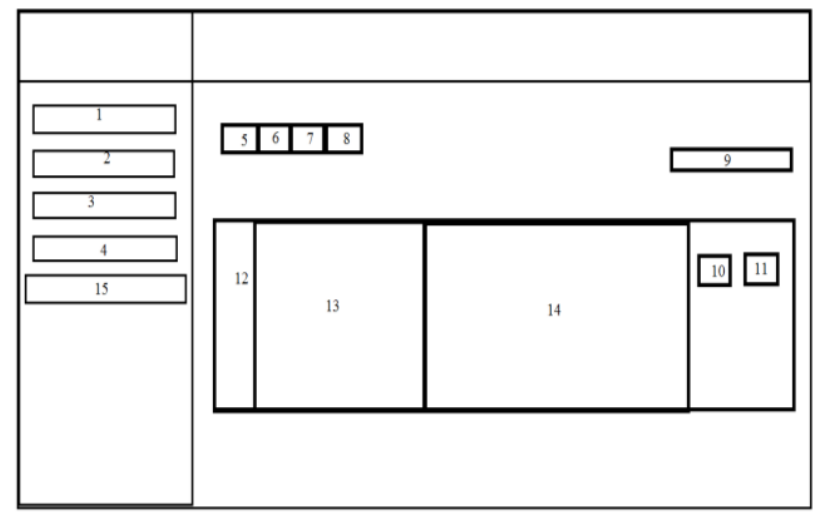

Fig. 6 Place View Sketch

Information :

1. Dashboard menu

2. Menu coordinates

3. Menu location

4. Menu Place

5. Copy

6. Exel

7. CVS

8. PDF
9. Search

10. Edit

11. Delete

12. Number

13. Place

14. Coordinates

15. Logout

\section{RESULTS AND DISCUSSION}

This test is done to check whether when we input the location it has been saved or not if it will appear on the coordinates in the form of a button, and the button will turn red and the marker appears, what if the microcontroller sends data that there are vehicles parked in location where there is a prohibited sign of parking. Button will return to its original blue color and the marker will disappear, if the sensor no longer detects a parked vehicle. For more details, train the picture below.

\subsection{Testing the detection of the location of traffic signs}

The test displays a marker with the address of the location of the research object

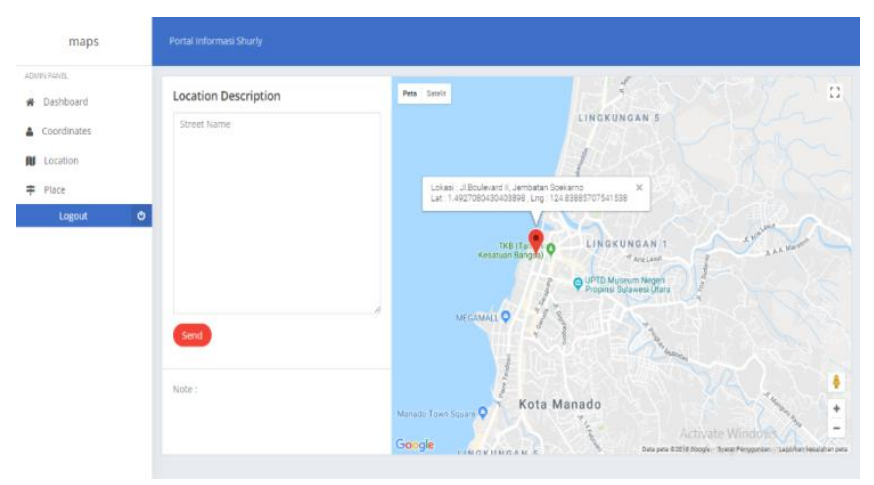

Fig. 7 testing when a violation is detected

\subsection{Archive Download Testing}

In this test the data in place can be used as archive documents in the form of PDF, CVS, Exel, and can also be copied, to be used as needed.

Potal hommasisury

\begin{tabular}{|c|c|}
\hline Place & Cordinates \\
\hline $\begin{array}{l}1 \text { Descipition: UY. Yos Sudarso, Depan pasa } \\
\text { seegar }\end{array}$ & 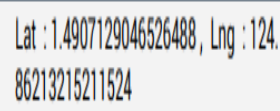 \\
\hline $\begin{array}{l}2 \text { Description: U. Boulevard II, Jembatan } \\
\text { Soekearno }\end{array}$ & 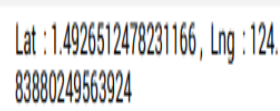 \\
\hline
\end{tabular}

Fig.8 Format PDF 


\subsection{Testing voice Response}

Table 1. Testing the response voice detection system, traffic signs

\begin{tabular}{|c|c|c|c|c|}
\hline No & Coordinate & $\begin{array}{c}\text { Types of } \\
\text { Signs-traffic } \\
\text { signs }\end{array}$ & $\begin{array}{c}\text { The } \\
\text { distance to } \\
\text { the } \\
\text { coordinates } \\
\text { of the traffic } \\
\text { signs }\end{array}$ & $\begin{array}{c}\text { Respon } \\
\text { voice }\end{array}$ \\
\hline 1 & $\begin{array}{c}1.490659, \\
124.839181\end{array}$ & Traffic Light & $\begin{array}{c}\langle=30 \mathrm{~m}>= \\
25\end{array}$ & On \\
\hline 2 & $\begin{array}{l}1.49338711, \\
124.8712912\end{array}$ & Traffic Light & $\begin{array}{c}<=30 \mathrm{~m}>= \\
25\end{array}$ & On \\
\hline 3 & $\begin{array}{c}1.50061624, \\
124.89123154\end{array}$ & Traffic Light & $\begin{array}{l}<=30 \mathrm{~m}>= \\
25\end{array}$ & On \\
\hline 4 & $\begin{array}{c}1.4940721, \\
124.88214505\end{array}$ & Traffic Light & $\begin{array}{c}<=30 \mathrm{~m}>= \\
25\end{array}$ & On \\
\hline 5 & $\begin{array}{c}1.4964506 \\
124.87745449\end{array}$ & Traffic Light & $\begin{array}{l}<=30 \mathrm{~m}>= \\
25\end{array}$ & On \\
\hline 6 & $\begin{array}{c}1.536177, \\
124.83865073\end{array}$ & Traffic Light & $\begin{array}{l}<=30 \mathrm{~m}>= \\
25\end{array}$ & On \\
\hline 7 & $\begin{array}{l}1.48994913, \\
124.8386679\end{array}$ & Traffic Light & $\begin{array}{l}<=30 \mathrm{~m}>= \\
25\end{array}$ & On \\
\hline 8 & $\begin{array}{c}1.518071, \\
124.887290\end{array}$ & Traffic Light & $\begin{array}{l}<=30 \mathrm{~m}>= \\
25\end{array}$ & On \\
\hline 9 & $\begin{array}{c}1.491029, \\
124.838260\end{array}$ & Traffic Light & $\begin{array}{c}<=30 \mathrm{~m}>= \\
25\end{array}$ & On \\
\hline 10 & $\begin{array}{c}1.50073788, \\
124.89165705\end{array}$ & $\begin{array}{c}\text { traffic } \\
\text { Climbs }\end{array}$ & $\begin{array}{l}<=30 \mathrm{~m}>= \\
\quad 25\end{array}$ & On \\
\hline 11 & $\begin{array}{c}1.492098, \\
124.838604\end{array}$ & $\begin{array}{c}\text { Signs } \\
\text { Prohibited } \\
\text { Parking }\end{array}$ & $\begin{array}{c}<=30 \mathrm{~m}>= \\
25\end{array}$ & On \\
\hline 12 & $\begin{array}{c}1.505280, \\
124.842987\end{array}$ & $\begin{array}{l}\text { forbidden to } \\
\text { turn right }\end{array}$ & $\begin{array}{l}<=30 \mathrm{~m}>= \\
25\end{array}$ & On \\
\hline 13 & $\begin{array}{c}1.499781, \\
124.845568\end{array}$ & $\begin{array}{l}\text { prohibited } \\
\text { left turn }\end{array}$ & $\begin{array}{c}<=30 \mathrm{~m}>= \\
25\end{array}$ & On \\
\hline
\end{tabular}

\section{CONCLUSIONS}

This system application is made to provide convenience to Transportation Agency officers, where the application is a control application that can control areas that have prohibited parking restrictions in accordance with latitude and longtitude. So that officers are easier to find out quickly if someone parked their vehicle in a area with prohibited signs. In the area where there are prohibited signs for parking there is a sensor so that if the sensor detects a vehicle, the sensor will send data to the web so the buttons on the web will be activated automatically, and if the sensor no longer reads the vehicle, the data is sent back to web so that the button will return to normal. The system can process the inputting data of places where there are prohibition signs forbidden to automatically become outputs in the form of document archives that can be accessed and downloaded by the admin to be used as needed.

\section{ACKNOWLEDGMENTS}

Thanks to the Ministry of Research and Technology of Technology and Higher Education, which has funded this research with competitive grants program in 2018 , so as to do research and work well.

\section{REFERENCES}

[1] Abu Bakr Iskandar.DKK. 1995. Towards Traffic and Road Transport are tongue, Jakarta. Directorate General of Land Transportation.

[2] Aries Setijadi, Road Traffic Congestion Study Kaligawe City Semarang, Semarang Diponigoro University thesis

[3] Afrias Sarotama, Mohammad M. Sarinato, Juniar Ganis, Development of Interactive Electronic Map, proceedings KOMMIT 2002

[4] Bob D. Sinulingga, Urban Development and Regional Local Review,Publisher Pustaka Sinar Harapan, 1999.

[5] D.Setijowarno \& RB Frazila, Introduction to Transportation Systems, Publisher Catholic University of Semarang Soegijapranata 2001

[6] Eko Budihardjo, the City Spatial Urban, Publisher Alumni, 1997

[7] HA Abbas Salim, Transportation Management, Publisher PT. King Grafindo Persada Jakarta, 1993. [8] Hadihardja, Joetata. DKK. 1997.Sistem Transportation. Jakarta. Publisher Guna Darma.

[8] Sugiyono, "Understanding Qualitative Research", Bandung, Alfabeta 2012.

[9] W. Gulo, Research Methodology, Grasindo Publishers, 2002.

[10] Ofyar Z. Tamin, planning and transport modeling, Publisher ITB Bandung, 2000. James Marson Budiman, Zahir Zahinuddin, Amil Ahman Ilham, Monitoring and Control Systems Urban traffic .Jurnal Hasanuddin University, 2012.

[11] Andy AM Malik, identification of traffic congestion in the city center Paal2 and Manado. Sam Ratulangi University in Manado, 2011.

[12] Warpani.S, plainly traffic management and road transportation, ITB, Bandung, 2002.

[13] Mokhamat Ansori, Mohammad Kanzunnudin, Application Traffic Management in the field of transportation, STIEPARI, Semarang, 2000.

[14] Budiman, Marson James, Stephy Walukow, and Herry Makapedua. "Development of Intelligent Transport System for Detection System Location Traffic Accidents." Development 151.11 (2016).

[15] Budiman, Marson James, Stephy Walukow, and Indri Patolenganeng. "Pengembangan Sistem Pemberi Isyarat Jenis Rambu Lalu Lintas Bagi Pengguna kendaraan Bermotor Berbasis GPS." Prosiding Industrial Research Workshop and National Seminar. Vol. 8. No. 3. 2017 